\title{
BADANIE ROLI CZYNNIKA NIEPEŁNOSPRAWNOŚCI W TWORZENIU UMYSLOWEJ REPREZENTACJI KATEGORII ZŁOŻONEJ
}

Streszczenie: Artykuł stanowi przyczynek do badań nad integracją poprzez sugestię uzupełnienia ich o badania psychosemantyczne, których przedmiotem są mentalne reprezentacje kategorii osób niepełnosprawnych. Proponuje się tu badanie struktury kategorii odnoszących się do podgrup osób niepełnosprawnych, podlegających tzw. wielokrotnej opresji. Kategorie takie należy rozpatrywać jako złożone, stanowiące subkategorie więcej niż jednej kategorii nadrzędnej/prostej, a strukturę kategorii złożonej można ujmować $\mathrm{w}$ terminach stopnia podobieństwa do każdej z kategorii nadrzędnych. W artykule przedstawiono przykład badania psychosemantycznego dotyczącego kategorii kobiet niepełnosprawnych. Niepowtarzalna specyfika opresji, charakterystyczna dla tej podgrupy, wyznaczająca budowę kategorii złożonej i jej związek z kategoriami nadrzędnymi (kategorią kobiety i osoby niepełnosprawnej), wynika z postrzegania dysfunkcji jako czynnika oddalającego kobiety niepełnosprawne od prototypowej kobiecości, utrudniającego pełnienie tradycyjnych ról kobiecych. Wyniki badania testem skojarzeń i testem skal potwierdzają duże różnice między kategorią kobiet z niepełnosprawnością i ogólną kategorią kobiety, a jednocześnie znacznie silniejszą i dominującą rolę czynnika niepełnosprawności w budowie tej kategorii złożonej.

Słowa kluczowe: pojęcia, reprezentacja umysłowa, pamięć semantyczna, słownik umysłowy, niepełnosprawność, feminizm, kobieta niepełnosprawna, integracja

\section{Wstęp: przedmiot badań psychosemantyki}

Przedmiot zainteresowań i badań dziedziny określanej jako psychosemantyka stanowią pojęcia - umysłowe reprezentacje ${ }^{1}$ kategorii kryjące się pod określonymi

1 Rozważania nad istotą reprezentacji umysłowych wykraczają poza ramy tego artykułu. Jako bazę teoretyczną przyjmuje się tu podejście traktujące reprezentację umysłową jako „własność lub aspekt stanu mentalnego albo też towarzyszący stanowi mentalnemu stan fizyczny, jak stan 
wyrazami. Z punktu widzenia teorii językoznawczych stanowią one konstrukt pośredniczący między znakiem językowym (wyrazem, wyrażeniem) a elementem rzeczywistości, do której znak się odnosi, czyli denotatem znaku². Natomiast według psychologii procesów poznawczych pojęcia to struktury poznawcze stanowiące jeden $\mathrm{z}$ typów informacji budujących deklaratywną pamięć semantyczną. Termin „pamięć semantyczna”, używany od lat 6o. XX wieku, oznacza system wiedzy o świecie, który w zmodyfikowanej wersji wielomagazynowego (blokowego) modelu procesów przetwarzania informacji interpretowany jest jako istotna część magazynu pamięci długotrwałej (Tulving 1972).

Ponieważ punktem wyjścia badań tego typu jest ekspozycja wyrazów lub/i wyrażeń danego języka, a więc ekspozycja nazwy pojęcia, następnie jej percepcja przez respondenta i aktywizowanie określonej wiedzy pod wpływem tej percepcji, dlatego perspektywa badawcza musi uwzględniać założenia dotyczące leksykonu umysłowego. Leksykon (słownik) umysłowy jest tu rozumiany jako „the stored mental representation of what people know about their language" (Crystal 1992, za: Neef, Vater 2006, s. 28), czyli jako wiedza na temat wszelkich aspektów leksyki danego języka, funkcjonująca w umyśle użytkownika tego języka. Słownik umysłowy jest zatem ściśle powiązany z pamięcią semantyczną lub można go nawet uważać za jej częśćs.

W świetle faktu, że stosunek do osób niepełnosprawnych i działania ukierunkowane na integrację traktuje się obecnie jako jeden ze wskaźników rozwoju cywilizacji, zasadne wydaje się rozszerzanie rozważań nad kwestiami związanymi $\mathrm{z}$ niepełnosprawnością na różnorodne pola badań, w tym również na badania psychosemantyczne, dostarczające danych interdyscyplinarnych, z pogranicza z jednej strony językoznawstwa, a z drugiej - psychologii i socjologii.

Analizy psychosemantyczne - dotyczące reprezentacji umysłowych kategorii związanych z niepełnosprawnością - można zatem traktować jako uzupełnienie wyników badań psychologicznych, pedagogicznych i socjologicznych nad problemami dysfunkcji i integracji. Jednocześnie jednak mogą one wyznaczać nowe ścieżki badań psycholingwistycznych ze względu na specyfikę badanych kategorii.

mózgu, za pośrednictwem którego stan mentalny odnosi się do stanu świata” (definicja według A. Klawitera, cyt. za: Zahorodna 2015, s. 17).

2 Taką relację elementów „znak”, „pojęcie” i „rzeczywistość” przedstawia się w postaci tzw. trójkąta semiotycznego. Każdy z trzech elementów jest reprezentowany przez jeden z wierzchołków, a bok łączący wierzchołki obrazujące odpowiednio „znak językowy” i „rzeczywistość” stanowi linię przerywaną, wskazując jako element pośredniczący „pojęcie”, czyli wiedzę użytkownika języka na temat fragmentu rzeczywistości, kryjącą się pod tym znakiem (Ogden, Richards 1923).

3 Relacje między leksykonem umysłowym a pamięcią semantyczną, w tym między pojęciem a mentalnym znaczeniem wyrazu, stanowią przedmiot sporów i rozważań (por. np. Aitchison 2003; Levinson 1999; Martínez-Manrique 2010; Mikołajczak-Matyja 2008). 


\section{Specyfika kategorii związanych z niepełnosprawnością: czynniki warunkujące siłę granic kategorii}

O specyfice kategorii kształtowanych przez niepełnosprawność ${ }^{4}$, a więc przez właściwości odróżniające określoną grupę ludzi od reszty społeczeństwa, decyduje istnienie zarówno czynników osłabiających, jak i czynników wzmacniających granice takich kategorii.

Sposób wyznaczania i definiowania kategorii osób niepełnosprawnych podlega silnym przemianom, uwarunkowanym m.in. różnymi aspektami polityczno-ekonomicznego rozwoju społeczeństw i postępem teorii naukowych. Oficjalnym przejawem i wyznacznikiem tych przemian jest ewolucja tzw. modeli niepełnosprawności, w różny sposób określających jej przyczyny i istotę. Ewolucja przebiega przede wszystkim od ścisłego wiązania niepełnosprawności z relacją człowiek - siły nadprzyrodzone (głównie w ramach różnych wierzeń religijnych), a więc traktowania jej jako zasłużonej kary za wykroczenie przeciwko normom lub jako przeznaczenia (model moralny), do modeli zobiektywizowanych, unaukowionych, pozostających pod wpływem determinizmu biologicznego (modele medyczne, w tym także psychologiczne oraz modele opieki i pomocy) oraz społecznego (model społeczny) (Dykcik 2005, za: Grzesiak 2011/2012; Fawcett 2000; Przyłuska-Fiszer 2013). Współczesne debaty na ten temat są zdominowane przez polaryzację „model medyczny a społeczny” (Fawcett 2000) i dążenie do wypracowania między nimi równowagi (Przyłuska-Fiszer 2013).

W modelach medycznych istotą niepełnosprawności jest występujące u danej jednostki biologiczne odchylenie od normy zdrowotnej, a więc: choroba, uszkodzenie ciała, upośledzenie, skutkujące ograniczeniem czy deficytem funkcjonowania wymagającym leczenia i opieki ze strony osób zdrowych i sprawnych. W model ten wpisane jest zatem ujmowanie osoby niepełnosprawnej jako zależnej i wymagającej pomocy. Natomiast w modelu społecznym (inaczej modelu barier społecznych) siła i zakres niepełnosprawności wyznaczone są przez stopień, w jakim struktura społeczna ogranicza aktywność i zaspokajanie potrzeb osoby z jakimkolwiek odchyleniem od normy zdrowotnej; niepełnosprawność stanowi formę społecznej opresji, jest bowiem uwikłana bezpośrednio w sposób funkcjonowania społeczeństwa, którego elementem jest taka osoba (Barnes, Mercer 2003; Fawcett 2000; Gorajewska 2006; Lejzerowicz, Książkiewicz 2012; Oliver 1996; Przyłuska-Fiszer 2013).

Jednym z efektów akceptacji modelu społecznego i jego pochodnych jest silne podkreślanie w najnowszej literaturze przedmiotu względności i płynności granic kategorii niepełnosprawności (np. Eyre 2014; Smith 2004).

\footnotetext{
${ }^{4}$ W pracy tej jako punkt wyjścia przyjmuje się socjologiczne rozumienie pojęcia niepełnosprawności, wskazujące jako jej kryterium przede wszystkim istnienie uszkodzeń bądź ograniczeń funkcjonalnych organizmu (na skutek chorób, urazu lub wad wrodzonych) oraz wynikające z tych uszkodzeń i ograniczeń skutki dla funkcjonowania społecznego osób nimi dotkniętych (Ostrowska 2000, s. 334).
} 
Postrzeganie granic tej kategorii jako nieszczelnych, niedokładnie oddzielających grupę tzw. niepełnosprawnych od tzw. pełnosprawnych to także rezultat coraz silniejszego uświadamiania sobie konieczności i powszechności ograniczeń ludzkiego funkcjonowania - zawężenia samowystarczalności tylko do określonych przedziałów w fazach rozwoju i ograniczania sprawności w różnych obszarach działań, zależnie od indywidualnych cech fizycznych i psychicznych. Niepełnosprawność można zatem postrzegać w wymiarze ciągłym (Fawcett 2000; Garland-Thomson 2004; Lejzerowicz, Książkiewicz 2012; Nussbaum 2001, za: Przyłuska-Fiszer 2013; Shakespeare 1996).

Z drugiej strony, istnieją także czynniki wzmacniające granice kategorii niepełnosprawności w umyśle jednostki poznającej (zwłaszcza takiej, która nie zajmuje się zawodowo problematyką niepełnosprawności). Należą do nich między innymi:

- Budowanie kategorii niepełnosprawności (nawet bardzo szerokiej) zawsze na zasadzie podkreślania opozycji z tym co pozytywne, np. zdrowe, piękne czy normalne (Garland-Thomson 2004).

- Lęk i niepewność związane z własnym funkcjonowaniem i cechami osoby pełnosprawnej, z uświadomieniem sobie nietrwałości zdrowia i niebezpieczeństwa utraty samodzielności, a nawet bliskości czy realności śmierci (Barnes, Mercer 2003; Biernat, Dovidio 2003; Ostrowska 2002). Kategoria niepełnosprawności należy zatem do tych, z którymi społeczeństwo zdecydowanie nie chce się identyfikować (Fawcett 2000). W przeciwieństwie do innych odmienności (zawodowej, narodowej czy nawet religijnej) ta spowodowana dysfunkcją skutkującą niepełnosprawnością jest postrzegana jako niepodlegająca kontroli i wyborom, a więc potencjalnie zagrażająca.

- Nazwy kategorii budowane na zasadzie dodawania elementu negatywnego, a zatem wzmacniające przeciwstawienie, jak nie + pełnosprawność w języku polskim, dys + funkcja lub dis + ability w języku angielskim. Wzmagają one poczucie odmienności u osoby, która uważa się za pełnosprawną, w stosunku do przedstawicieli kategorii osób niepełnosprawnych.

Wyraźnego odczuwania odmienności i biegunowego pojmowania różnicy między osobą z dysfunkcją i bez dysfunkcji nie zmienia ani brak ustalonej naukowo ostrej granicy na kontinuum pełnosprawność - niepełnosprawność, ani podważanie przez specjalistów opozycji niepełnosprawność - normalność (por. Byra 2010; Eyre 2014).

Efektem działania wymienionych czynników wzmacniających granice interesujących nas kategorii jest także specyfika środków i sytuacji społecznych, decydujących o przekazywaniu i rozpowszechnianiu wiedzy na temat niepełnosprawności. We współczesnym świecie rozwój i utrwalanie kategorii w umysłach przedstawicieli społeczeństw są w coraz większym stopniu uwarunkowane nie tylko przebiegiem bezpośredniej komunikacji (w tym przypadku zarówno między osobami pełnosprawnymi, jak i między pełnosprawnymi a niepełnosprawnymi), ale także oddziaływaniem literatury i malarstwa, a przede wszystkim środków masowego przekazu typu radio, telewizja, reklamy czy internet. W przypadku informacji dotyczących niepełnosprawnych istotny okazuje się zarówno sposób przedstawiania sytuacji 
osób należących do tej kategorii ${ }^{5}$, jak i - może nawet w większym stopniu - stopień pomijania ich w przekazach. Już pod koniec XX wieku zwracano uwagę na nikły udział niepełnosprawnych w programach telewizyjnych nadawanych w dobrym czasie antenowym, w tym informacyjnych (Gerbner 1993, za: Renzetti, Curran 2003). W ostatnich dziesięcioleciach widoczne są wprawdzie pewne zmiany, polegające np. na wprowadzaniu niepełnosprawności jako ważnego (i budzącego pozytywne skojarzenia) wątku w dziełach literackich i scenariuszach filmowych, jednak osoby niepełnosprawne nadal rzadko są bohaterami tak znaczących przekazów, jak reklamy produktów o przeznaczeniu ogólnym, nie tylko dla osób z określoną dysfunkcją (Łuszczyńska, Baum 2011/2012), oraz mediów typu internet i intranet (np. w przeprowadzonej niedawno analizie pewnego szkolnego intranetu stwierdzono „wirtualną nieobecność” osób niepełnosprawnych, por. Hodkinson 2014). „Wirtualne pomijanie” tematu niepełnosprawności w dobie coraz większego społecznego i cywilizacyjnego znaczenia przekazów zamieszczanych w sieci może stanowić jeden z czynników powodujących zubożenie treści kategorii związanych z tym tematem w świadomości społecznej, czyli w zasobach wiedzy osób pełnosprawnych, a w każdym razie zmniejsza szansę na budowanie tej kategorii $z$ informacji rzetelnych i wszechstronnych.

\section{Podgrupy osób niepełnosprawnych a struktura kategorii: subkategorie i kategorie złożone}

Na przestrzeni ostatnich kilkudziesięciu lat w literaturze dotyczącej osób z niepełnosprawnością coraz częściej postuluje się konieczność rozpatrywania problemów wynikających ze wzajemnego oddziaływania takich cech podgrup przedstawicieli tej grupy, jak: płeć, rasa, narodowość, wiek czy klasa społeczna. Podgrupy te mogą być badane (i nazywane) w różny sposób, np. jako oparte na wielokrotnych czynnikach wyznaczających mniejszość społeczną (multiple minority groups w odróżnieniu od single minority groups, por. Deegan 1985) lub jako powstające w wyniku nakładania się wielokrotnych tożsamości (intersections of multiple identities, por. O’Toole 2004; Garland-Thomson 2000, za: O'Toole 2004).

Badanie takich podgrup z perspektywy psychosemantycznej wiąże się z rozpatrywaniem relacji między kategorią a subkategoriami oraz między kategorią prostą a kategoriami złożonymi.

Zajmowanie się subkategoriami oznacza konieczność w pisywania interpretacji badań w hierarchizowanie pojęć, jeden z podstawowych sposobów porządkowania

\footnotetext{
5 W kulturze Zachodu różne formy niepełnosprawności fizycznej (np. garb, hak zamiast ręki) bywały wykorzystywane jako metafora zła i deprawacji przeciwstawianej „pięknej dobroci” (Connor, Bejoian 2007). Współczesne przekazy są dość różnorodne, częste jest jednak pokazywanie niepełnosprawnych jako osób biernych, słabych, niezdolnych do „normalnego” życia, jako cierpiących ofiar lub ewentualnie, na zasadzie kontrastu, jako mających niezwykłe osiągnięcia (Longmore 1987, za: Barnes, Mercer 2003; Panek 2012).
} 
świata przez człowieka. Istotność powiązań wyznaczonych przez podziały kategorii (np. PTAK) na subkategorie (np. WRONA, KOLIBER itd.) stanowi jedno z głównych założeń budowy tak pamięci semantycznej, jak i leksykonu umysłowego ${ }^{6}$. Interdyscyplinarne badania nad tzw. taksonomiami potocznymi dowiodły uniwersalności organizacji hierarchicznej jako właściwości sposobu kategoryzowania i nazywania świata w różnych kulturach (por. np. Atran 1999; Conklin 1962).

W przypadku systemu kategorii naukowych, stanowiących zbiory cech koniecznych i wystarczających, każdą subkategorię budują wszystkie cechy odziedziczone z kategorii nadrzędnej oraz dodatkowo cechy odróżniające tę subkategorię od innych subkategorii tej samej kategorii, np. kategoria KOLIBER zawiera cechy typu: ma dziób, skrzydła oraz cechy: barwny, bardzo mały (jakna ptaka) czy żyjący w Ameryce. W przypadku kategorii o charakterze potocznym, nienaukowym, przynajmniej niektóre cechy (niekiedy większość lub nawet wszystkie) nie mają charakteru właściwości koniecznych, są zatem trudne do wyodrębnienia i nie jest łatwo przewidzieć kompletność ich dziedziczenia przez subkategorie. Trudność ta zwiększa się jeszcze w przypadku kategorii o charakterze społecznym, których ważnym elementem są cechy o charakterze emocjonalnym i wartościującym.

Subkategorie kategorii społecznych wyznaczone przez płeć, wiek, rasę itp. stanowią poziom (bezpośrednio) podrzędny w stosunku do dwóch lub nawet więcej kategorii, np. EUROPEJKA to bezpośrednia subkategoria kategorii KOBIETA i EUROPEJCZYK. Subkategoria EUROPEJKA stanowi tzw. kategorię złożoną, ponieważ potencjalnie może być zbudowana $\mathrm{z}$ cech wchodzących w skład obu kategorii nadrzędnych (określanych w tym przypadku także jako proste) plus, oczywiście, z cech bardziej szczegółowych, wyodrębniających tę subkategorię wewnątrz każdej z kategorii nadrzędnych.

Kategorie złożone mogą wykazywać swoistą odrębność czy nawet względną niezależność w stosunku do obu kategorii prostych, nadrzędnych. Zdaniem Davida J. Schneidera niezależność ta może w strukturze kategorii złożonej przejawiać się dwojako: poprzez zmniejszanie proporcji cech dziedziczonych od kategorii prostych oraz poprzez uwydatnianie się cech, które w kategoriach prostych są nieistotne. Zjawiska te określane są przez niego odpowiednio jako inheritance failure i emergent properties (Schneider 1999, s. 342; Schneider 2004, s. 81). Ważnym punktem analizy kategorii złożonej jest zatem pytanie o wielkość różnicy w stopniu dziedziczenia przez nią cech z poszczególnych kategorii nadrzędnych, czyli: czy kategoria EUROPEJKA ma więcej cech przejętych z kategorii EUROPEJCZYK, czy z kategorii KOBIETA?

W naukach społecznych problem ten przekłada się na pytanie o sposób kategoryzowania obiektów społecznych w różnych sytuacjach, tj. o uaktywnienie cech należących tylko do jednej z dwóch lub więcej kategorii (prostych). Z badań

\footnotetext{
${ }^{6}$ Por. np. modele pamięci semantycznej Collinsa i Quilliana, Collinsa i Loftus lub Millera i Johnsona-Lairda, w których relacja nadrzędności - podrzędności odgrywa bardzo istotną rolę (Collins, Quillian 1969; Collins, Loftus 1975; Miller, Johnson-Laird 1976).
} 
wynika, że w takich przypadkach istnieje możliwość przypisania osoby do jednej z kategorii, przy czym zaktywizowanie cech tej kategorii blokuje dostęp do danych z kategorii pozostałych, np. zaliczenie Europejki do kategorii KOBIETA utrudnia dostęp do informacji z kategorii EUROPEJCZYK (Macrae i in. 1995). Do najbardziej dostępnych i najłatwiej aktywizowanych należy (obok np. rasy czy wieku) kategoria płci, ze względu m.in. na wysoką diagnostyczność cech zewnętrznych (por. np. Kwiatkowska 1999; Schneider 1999).

Powyższe założenia i stwierdzenia mogą stanowić punkt wyjścia badania kategorii złożonych związanych z niepełnosprawnością.

\section{Założenia dotyczące budowy kategorii kobiet niepełnosprawnych w świetle problemu wielokrotnej opresji}

Kategorie kobiet niepełnosprawnych, zgodnie z założeniami podanymi wcześniej, należy rozumieć jako subkategorie kategorii prostych: KOBIETA oraz OSOBA NIEPEŁNOSPRAWNA. Badania nad reprezentacją kategorii kobiet niepełnosprawnych jako subkategorii czy kategorii złożonych (jak i innych subkategorii czy kategorii złożonych związanych z niepełnosprawnością) wiążą się z problematyką kombinacji różnych typów dyskryminacji, czyli podlegania tzw. wielokrotnej opresji (Deegan 1985; Oliver 1996). Punkty wyjścia rozważań na temat podgrupy niepełnosprawnych kobiet formułowane są przykładowo w postaci następujących stwierdzeń: doświadczanie niepełnosprawności jest w sposób nieunikniony zależne od płci (Morris 1993, za: Thomas 1999, s. 108), życie z podobnymi niepełnosprawnościami jest inne dla kobiet niż dla mężczyzn (Wendell 1996, za: Thomas 1999, s. 106), kobiety niepełnosprawne są zatem w gorszej sytuacji ekonomicznej, społecznej i psychologicznej niż pełnosprawne kobiety czy niepełnosprawni mężczyźni (Fine, Asch 1985, s. 7). W literaturze przedmiotu niejednokrotnie zwracano uwagę, że sytuację przedstawicieli podgrup, podlegających kombinacji różnych typów dyskryminacji, należy rozpatrywać nie jako skutek prostego dodawania doświadczeń charakterystycznych dla poszczególnych składników („pojedynczych opresji”), lecz jako doświadczenie „opresji jednoczesnej”, stanowiącej wynik wzajemnej interakcji poszczególnych składników, opresji o niepowtarzalnej specyfice, bo charakterystycznej jedynie dla tego połączenia składników (por. np. Barnes, Mercer 2003; Deegan 1985; Fawcett 2000; Graham 1997; Lonsdale 1990; Schur 2004; Stuart 1993, za: Thomas 1999; Thomas 1999; Vernon 1996). Właśnie niepowtarzalny charakter opresji może teoretycznie stanowić podstawę specyfiki kategorii złożonej i stopnia jej niezależności od jednej lub obu kategorii prostych (nadrzędnych).

Punktem wyjścia badania budowy kategorii KOBIETA NIEPEŁNOSPRAWNA jako kategorii złożonej jest zatem określenie siły oddziaływania czynników wywołujących opresję - płci i niepełnosprawności.

Wydaje się, że dobrą podstawą teoretyczną rozważań na temat siły tych dwóch czynników i specyfiki opresji, jakim podlegają kobiety z niepełnosprawnością, 
są próby określenia możliwości pełnienia przez nie określonych ról: rodzinnych, społecznych i ekonomicznych. W szczególności postrzeganie ich jako nienadające się do pełnienia ról typowo kobiecych może sprawić, że kategorie KOBIET NIEPEŁNOSPRAWNYCH będą w postrzeganiu społecznym odmienne od kategorii KOBIETY. Zainteresowanie problemem efektywnego pełnienia przez kobiety z dysfunkcją tradycyjnych żeńskich ról - żony, partnerki seksualnej oraz matki - znalazło wyraz w bogatej literaturze przedmiotu, w tym także, zwłaszcza w ostatnim dziesięcioleciu, literaturze polskiej. Poniżej przedstawione zostaną zatem jedynie podstawowe stwierdzenia dotyczące tej problematyki.

$Z$ badań statystycznych wynika, że kobiety niepełnosprawne są rzadziej zamężne, później wychodzą za mąż, częściej są rozwiedzione lub w separacji niż kobiety pełnosprawne (por. np. Fine, Asch 1985; Kutza 1981; Lonsdale 1990; Nowak 2012 i wiele innych). Przyczyn tego zjawiska należy upatrywać w złożonej interakcji czynników psychologicznych, fizycznych i społecznych. Po pierwsze, niektóre rodzaje dysfunkcji mogą spowodować większą koncentrację kobiety na funkcjonowaniu organizmu, uszkodzonym narządzie i leczeniu, co może prowadzić do osłabienia postrzegania ciała jako ośrodka wrażeń seksualnych i osłabienia procesu rozwoju tożsamości płciowej. Ciało może być postrzegane jako bariera, a nie ośrodek wrażeń seksualnych (Nowak 2012). Po drugie, istnieje utrwalony kulturowo stereotyp kobiety niepełnosprawnej jako aseksualnej, nieatrakcyjnej (pozostającej zatem poza sferą kobiecości i kobiecego piękna), niemogącej dobrze pełnić roli partnerki seksualnej (por. np. Fine, Asch 1985, 1988; Garland-Thompson 2004; Lonsdale 1990; Matthews 1983). Wyrazem i skutkiem tego stereotypu są społeczne oczekiwania i naciski, by rezygnować $\mathrm{z}$ ról płciowych, w tym także odpowiednio ukierunkowane działania instancji zajmujących się socjalizacją osób niepełnosprawnych, pomijające seksualne aspekty życia. Efektem może być brak przygotowania do pełnienia ról płciowych, który w połączeniu z naciskami zakazującymi lub zniechęcającymi do ich podejmowania powoduje lęk i wycofywanie się. W sferze psychicznej pojawiają się utrudnienia dotyczące pogodzenia obrazu Ja i tradycyjnego pojęcia kobiecości (Lonsdale 1990; Nowak 2012).

Jednym z podstawowych czynników decydujących o sile opisywanego mechanizmu wydaje się być identyfikowanie się z własnym ciałem jako istotna cecha kobiecości. W opinii społecznej kobiety są stereotypowo identyfikowane z ciałem (Edwards 1987, za: Lonsdale 1990), oceniane przez pryzmat wyglądu i fizycznej atrakcyjności (Marszałek 2006; Nowak 2012). Internalizacja tego poglądu stwarza możliwość utożsamiania obrazu Ja z obrazem ciała. Niepełnosprawność może przyczyniać się w znacznym stopniu do wytworzenia negatywnego obrazu własnego ciała, niezgodnego z wzorcami przyjętymi w danej kulturze i internalizowanymi przez jej członków (Lonsdale 1990). Zwraca się również uwagę, że brak kobiecości, we własnym odczuciu kobiety niepełnosprawnej i w odczuciu otoczenia, bywa uwydatniany przez takie czynniki, jak: ograniczenie możliwości wyboru odzieży, sposób siedzenia lub poruszania się czy parawerbalne aspekty komunikacji (np. zaburzenia tempa i dynamiki mowy czy prozodii w przypadku zaburzeń słuchu) (Deegan 1985). 
Uzupełnieniem sposobu postrzegania kobiety niepełnosprawnej jako potencjalnej partnerki seksualnej i żony były aż do 2. połowy XX wieku przekonania społeczne dotyczące możliwości pełnienia przez nią roli matki. Również i ten przywilej „normatywnej kobiecości" był, i często nadal bywa, odmawiany kobiecie niepełnosprawnej - musi ona walczyć o uznanie nie tylko swojej seksualności, ale także prawa do rodzicielstwa (Fine, Asch 1988; Garland-Thomson 2004). Zdolność do urodzenia i wychowania dzieci jest postrzegana (nawet przez rodziny kobiet niepełnosprawnych) przez pryzmat kilkusilnych i dość wszechobecnych mitów. Są to, oprócz aseksualności, także: zależność i bierność, dziedziczność niepełnosprawności, konieczność fizycznej mobilności i ruchliwości w procesie opieki nad dzieckiem, a w efekcie konieczność cierpienia takich dzieci (Lonsdale 1990; Shaul i in. 1985). Takie społeczne przekonania mogą zostać przez kobietę niepełnosprawną zinternalizowane i zrodzić w niej przekonanie o niezdolności do pełnienia roli matki (Nowak 2012).

Konsekwencją przedstawionego stanu rzeczy jest m.in. kształtowanie się u kobiet niepełnosprawnych odmiennej motywacji do wycofywania się z ról kobiecych niż u kobiet pełnosprawnych. W badaniach przeprowadzonych kilka lat temu w Polsce stwierdzono, że respondentki pełnosprawne motywują ewentualną (rzadką) rezygnację z podejmowania ról żony i matki swoimi cechami psychicznymi, podczas gdy kobiety niepełnosprawne - przekonaniem o braku własnej atrakcyjności oraz niemożności zapewniania dzieciom właściwej opieki, obawą o pogorszenie swojego stanu zdrowia, a nawet istnieniem norm społecznych odnoszących się do niepełnosprawności (Marszałek 2006).

Różnice w społecznej ocenie możliwości pełnienia określonych ról przez kobiety pełnosprawne i niepełnosprawne znajdują odzwierciedlenie w skomplikowanym stosunku ruchów feministycznych do kobiet niepełnosprawnych. Kobiety te długo znajdowały się poza zasięgiem postulatów feministycznych (Barnes, Mercer 2003). Ich cele niełatwo jest bowiem pogodzić z celami feminizmu - istnieje wyraźna sprzeczność między dążeniami feministek do przezwyciężania stereotypów związanych z płcią, takich jak sztywne przypisywanie im określonych ról (zdaniem feministek kobieta nie powinna być postrzegana jako pełniąca jedynie rolę partnerki seksualnej, żony, matki), a faktem, że dla kobiety niepełnosprawnej pełnienie tych ról może być celem trudnym do osiągnięcia (Barnes, Mercer 2003; Fine, Asch 1985; Meekosha, Dowse 1997; Mikołajczak-Matyja i in. 2013). Podkreśla się także skomplikowaną zależność między seksualnością jako ważną cechą kobiecości a postrzeganą aseksualnością kobiety niepełnosprawnej: potencjalnym problemem (ogółu) kobiet jest traktowanie ich jako obiektów głównie seksualnych, a kobiet niepełnosprawnych - jako obiektów aseksualnych (Deegan 1985; Garland-Thomson 2004; Hahn 1988, za: Garland Thomson 2004; Kent 1977, za: Deegan 1985).

7 Te skomplikowane relacje rodzą dodatkowe problemy dla kobiet niepełnosprawnych pragnących włączyć się w ruch feministyczny. Jeśli kobieta niepełnosprawna, z przekonania feministka, decyduje się dobrowolnie na rezygnację z roli żony czy matki, to jej zachowanie może zostać 
Powyższe dane wskazują na możliwość określania specyfiki opresji w grupach kobiet niepełnosprawnych w terminach postrzegania dysfunkcji jako czynnika oddalającego je od prototypowej kobiecości. W literaturze przedmiotu można znaleźć zgodne z tym wnioskiem stwierdzenia, że niepełnosprawność stanowi fundamentalny czynnik opresji (Hearn, Parkin 1993, za: Fawcett 200o), wydaje się być najbardziej znaczącą cechą osoby, poprzez którą jest ona definiowana i etykietowana (Fine, Asch 1985), czy że kobiecie niepełnosprawnej przypisuje się raczej właściwości osoby niepełnosprawnej niż kobiety z racji siły negatywnego stereotypu niepełnosprawności (Byra 2010; Ostrowska, Sikorska 1997).

W dalszej części artykułu pokazany zostanie przykładowy sposób weryfikacji prawdziwości i aktualności tych stwierdzeń poprzez badania o charakterze psychosemantycznym.

\section{Metodologia i wyniki badań nad rolą niepełnosprawności jako czynnika budującego kategorię złożoną: przykład własny}

Cel badania, hipoteza, materiał badawczy i respondenci

W proponowanej tu badawczej perspektywie psychosemantycznej hipoteza dotycząca roli czynnika niepełnosprawności w określaniu specyfiki opresji kobiet z niepełnosprawnością sprowadza się do postulowania większej roli czynnika niepełnosprawności niż czynnika płci w budowaniu kategorii złożonej determinowanej przez oba te czynniki. Celem badania było zatem przeanalizowanie zawartości ponadindywidualnej reprezentacji kategorii, będącej efektem połączenia płci i niepełnosprawności jako czynników kategoryzacji, w terminach cech budujących taką reprezentację, a w szczególności porównanie jej z kategoriami wyznaczonymi odrębnie przez płeć i przez niepełnosprawność. Założono, że analizy takie pozwolą na określenie siły i roli niepełnosprawności jako czynnika budującego mentalne reprezentacje kategorii.

Weryfikowano zatem następującą hipotezę: cechy zbioru reakcji werbalnych, stanowiących efekt percepcji nazwy kategorii wyznaczonej przez czynniki: płeć + niepełnosprawność, są bliższe cechom zbioru reakcji wywołanych percepcją nazwy kategorii wyznaczonej przez niepełnosprawność niż kategorii wyznaczonej wyłącznie przez płeć.

Badano trzy kategorie: KOBIETA, INWALIDKA oraz INWALIDA, a hipoteza badawcza dotyczyła większej zgodności budowy pary INWALIDKA i INWALIDA niż pary INWALIDKA i KOBIETA. Szczegółowy dobór badanych kategorii uwarunkowany był specyfiką dziedziny, tj. problematyką struktury leksykonu umysłowego, a zatem charakterystyką nazw funkcjonujących w języku polskim. Starano

przez otoczenie zinterpretowane jako niedobrowolne, bo wynikające z niepełnosprawności (Lonsdale 1990). 
się wybrać nazwę (etykietkę kategorii) mającą określone właściwości: jednowyrazową, o jednoznacznej charakterystyce gramatycznej i stosunkowo prostej morfologicznie budowie (w odczuciu użytkowników języka polskiego) ${ }^{8}$. Rzecz jasna, badanie $\mathrm{z}$ użyciem takich form należy traktować jedynie jako jedną z możliwych egzemplifikacji omawianego tu problemu, a zasięg wniosków ograniczony jest do kategorii wyznaczonych dokładnie przez takie nazwy.

Do badania różnic między reprezentacjami kategorii wybrano dwie klasyczne, odmienne techniki badań psycholingwistycznych.

Pierwszą z nich jest generowanie w określonym, niewielkim przedziale czasu (2 minut) skojarzeń jako reakcji na percepcję nazwy-etykietki badanej kategorii, a więc technika umożliwiająca uzyskanie informacji w różnorodny sposób powiązanych z denotatem hasła. Otrzymane dane można interpretować w terminach teorii sieciowych pamięci semantycznej: zakłada się, że podstawą reakcji otrzymywanych w badaniu jest sieć powiązań o różnej sile między poszczególnymi pojęciami lub jednostkami leksykalnymi zmagazynowanymi w leksykonie umysłowym i w pamięci semantycznej. Zaktywizowanie nazwy-etykiety kategorii wywołuje automatyczną aktywizację nazw cech i zachowań skojarzonych z nazwą kategorii w magazynie pamięciowym.

Druga technika to ocenianie danej kategorii X na przygotowanych przez badacza skalach, mieszczących się między określeniami przeciwstawnymi (technika nawiązująca do dyferencjału semantycznego Osgooda). W terminach pamięci semantycznej i leksykonu umysłowego badana jest w tym przypadku subiektywna ocena odległości między wyrazami (między nazwami cech a nazwą badanej kategorii), dokonywana w określonym czasie.

Dzięki technice „samodzielnej aktywizacji” można wyodrębnić informacje najistotniejsze dla struktury pojęcia, natomiast technika skal z gotowym materiałem leksykalnym pozwala na dokładną ocenę siły czy roli poszczególnych cech, w tym bardziej szczegółowych.

W badaniu nie chodziło o uzyskanie obrazów reprezentatywnych dla całej społeczności językowej, lecz o wskazanie podobieństw i różnic między reprezentacjami rekonstruowanymi na podstawie odpowiedzi uzyskanych od porównywanych, z założenia równoważnych grup. Porównywane dane, otrzymane przy wykorzystaniu jednej techniki, pochodziły od niewielkich, czterdziestoosobowych grup. Każdy respondent udzielał odpowiedzi tylko na jedno hasło i przy wykorzystaniu tylko jednej techniki: nie chodziło bowiem o bardziej lub mniej świadome dokonywanie porównań między kategoriami przez samych respondentów ani o reakcje

\footnotetext{
8 Syntagmy kobieta niepełnosprawna/mężczyzna niepetnosprawny, kobieta/mężczyzna z niepełnosprawnością lub nawet określenia jednowyrazowe niepełnosprawna/niepełnosprawny, choć mają znaczenia nieco szersze i bardziej neutralne niż inwalida, nie spełniają powyższych kryteriów. Ponadto poza dyskursem naukowym terminy inwalida/inwalidka są nadal, jak się wydaje, stosowane przez niespecjalistów znacznie częściej.
} 
relatywizowane względem siebie w momencie badania, lecz o uzyskanie materiału niezależnego dla każdego z trzech haseł.

W badaniu uczestniczyło zatem sześć czterdziestoosobowych grup. Respondentami byli uczniowie polskich liceów ogólnokształcących (szkół masowych w dużych miastach, w momencie badania bez uczniów z dysfunkcjami), w wieku 15-18 lat, w każdej grupie byli przedstawiciele obu płci w proporcjach: jedna czwarta - trzy czwarte (wyższy udział, zależnie od grupy, dotyczył jednej lub drugiej płci) do pół na pół.

\section{Wyniki testu skojarzeń}

Stu dwudziestu respondentów, po 40 osób w każdej grupie, otrzymało następującą instrukcję: „Wypisz dowolną liczbę słów, które przychodzą Ci na myśl w związku z poniższym hasłem. Masz na to 2 minuty. Nie zastanawiaj się nad odpowiedzią i wyborem wyrazów". Otrzymano w sumie 1008 reakcji: 364 na hasło KOBIETA, 323 na hasło INWALIDKA i 321 na hasło INWALIDA. Analiza statystyczna przeprowadzona przy użyciu testu nieparametrycznego Kruskala-Wallisa (uprzednio przeprowadzone testy normalności Shapiro-Wilka i Lillieforsa wykazały, że rozkłady wyników dla haseł odbiegają od normalnego) pozwoliła na stwierdzenie braku istotnych statystycznie różnic między liczebnościami odpowiedzi na poszczególne hasła (wynik $\mathrm{H}=3,07, \mathrm{p}=0,3807$ ).

Połączenie identycznych reakcji podanych przez różnych badanych na dane hasło stanowiło podstawę wyznaczenia wskaźnika liczby różnych reakcji: KOBIETA 180, INWALIDKA - 190, INWALIDA - 192. Jako identyczne kwalifikowano jedynie odpowiedzi różniące się liczbą gramatyczną (np. proteza i protezy, dziecko i dzieci) oraz formy podstawowe i zdrobniałe (np. mama i matka).

Następnie określono stopień podobieństwa obrazów skojarzeniowych poprzez wyłonienie reakcji zbieżnych, wspólnych wewnątrz pary haseł INWALIDA/ INWALIDKA i wewnątrz pary haseł KOBIETA/INWALIDKA.

Tabela 1. przedstawia procentowy udział takich reakcji wspólnych dla członów obu par dla wskaźników: suma wszystkich reakcji dla danego hasła oraz liczba różnych reakcji.

Tabela 1. Udział (\%) reakcji wspólnych w korpusach reakcji

\begin{tabular}{lcccc}
\multirow{2}{*}{ Wskaźnik } & \multicolumn{2}{c}{ INWALIDA/INWALIDKA } & \multicolumn{2}{c}{ KOBIETA/INWALIDKA } \\
& INWALIDA & INWALIDKA & KOBIETA & INWALIDKA \\
\hline $\begin{array}{l}\text { Suma reakcji } \\
\begin{array}{l}\text { Liczba różnych } \\
\text { reakcji }\end{array}\end{array}$ & 50,2 & 49,2 & 8,8 & 6,5 \\
& 24,0 & 24,3 & 5,0 & 4,7
\end{tabular}


Zbiory reakcji dla pary INWALIDA/INWALIDKA cechuje znacznie większy stopień podobieństwa niż dla pary KOBIETA/INWALIDKA - reakcje wspólne stanowią około jednej czwartej każdego ze zbiorów różnych reakcji i aż połowę wszystkich wystąpień reakcji. Dla drugiej badanej pary udział reakcji identycznych dla żadnego ze wskaźników nie osiągnął 10\%. Sprawdzono istotność statystyczną różnicy między siłą zbieżności dwóch badanych par. Wskaźnik porównywany testem $\chi^{2}$ zbudowano przez obliczenie proporcji liczby reakcji identycznych dla danej pary do wskaźnika „liczba różnych reakcji” dla tej pary (dla pary INWALIDA/INWALIDKA wskaźnik 46/(192 + 190), porównywany z parą KOBIETA/INWALIDKA: 9/(180 + 190). Różnica okazała się istotna statystycznie, zbieżność między kategoriami INWALIDA/INWALIDKA jest istotnie silniejsza niż zbieżność w parze KOBIETA/ INWALIDKA: $\chi^{2}=25,6, p=0,00$. Hasło INWALIDKA wywołuje zatem raczej skojarzenia takie jak INWALIDA niż KOBIETA.

\section{Wyniki testu skal}

Sto dwadzieścia osób (po 40 w każdej grupie) otrzymało ankietę zawierającą 38 par przymiotników i 2 pary rzeczowników. Skontrastowane znaczeniowo przymiotniki/ rzeczowniki tworzące pary, rozdzielone siedmiopunktową skalą, miały być traktowane przez badanych jako bieguny jednego wymiaru. Wykorzystano następujące skale': nietowarzyski-towarzyski, głupi-madry, podporządkowany-dominujący, nieodpowiedzialny-odpowiedzialny, nieużyteczny-użyteczny, lękliwy-spokojny, nieprawdomówny-prawdomówny, odtwórczy-twórczy, konfliktowy-niekonfliktowy, nieuczciwy-uczciwy, nieuprzejmy-uprzejmy, bierny-aktywny, groźny-niegroźny, niepewny siebie-pewny siebie, zaniedbany-zadbany, lekkomyślny-rozważny, niesamodzielny-samodzielny, leniwy-pracowity, egoista-altruista, nieśmiały-śmiały, ponury-radosny, wrogi-przyjazny, marzyciel-realista, niekulturalny-kulturalny, apatyczny-energiczny, nietolerancyjny-tolerancyjny, słaby-silny, dziwaczny-zwyczajny, niedojrzały-dojrzały, agresywny-łagodny, niezdecydowany-stanowczy, zimny-ciepły, niezdolny-zdolny, podejrzliwy-ufny, zły-dobry, zależny-niezależny, niereligijny-religijny, nerwowy-zrównoważony, nieodporny-odporny, niezaradny-zaradny.

Zadanie polegało na zakreśleniu przez badanego takiego punktu na skali, którego odległość od bieguna/biegunów byłaby najbardziej zgodna $\mathrm{z}$ subiektywnym poczuciem związku między hasłem X a wyrazem stanowiącym nazwę bieguna/ biegunów. Zakreślenie punktu środkowego skali miało oznaczać jednakowy stopień powiązania X z jednym i drugim określeniem albo brak związku skali z X. Dla celów ujednolicenia obliczeń niskie wartości skali przypisano biegunom negatywnym, a wyższe - pozytywnym, czyli decyzji o bardzo silnym związku negatywnego bieguna z X przypisano wartość 1, o nieco mniej silnym związku z tym

${ }^{9}$ Kolejność skal: jak w ankiecie; kolejność biegunów: od mniej do bardziej pozytywnego (w ankiecie losowo). 
biegunem - wartość 2, o bardzo silnym związku z biegunem pozytywnym - wartość 7 itp. Sprawdzono istotność statystyczną różnic między wynikami uzyskanymi dla poszczególnych haseł (dla wszystkich par), dla każdej ze skal testu. Analizę statystyczną przeprowadzono przy użyciu nieparametrycznego testu Kruskala-Wallisa i analizy post-hoc z wykorzystaniem testu Dunna (uprzednio wykonane testy normalności wykazały, że w przypadku większości skal rozkład wyników odbiega od normalnego).

Dla następujących 16 skal wykazano istotność różnicy między kategoriami KOBIETA a INWALIDKA, a mianowicie KOBIETA okazała się istotnie bardziej: towarzyska, mądra, dominujaca, użyteczna, konfliktowa, aktywna, pewna siebie, zadbana, śmiała, radosna, energiczna, zdolna, samodzielna, niezależna, zaradna, twórcza niż INWALIDKA. Dane statystyczne zawiera tabela 2.

W przypadku pary INWALIDA/INWALIDKA różnica dla żadnej z 40 skal nie okazała się istotna. Zatem również to badanie wykazuje znacznie większe rozbieżności między zawartością ponadindywidualnych kategorii KOBIETA i INWALIDKA niż między kategoriami INWALIDA i INWALIDKA.

Tabela 2. Wyniki analizy statystycznej dla skal różnicujących w sposób istotny kategorie KOBIETA i INWALIDKA

\begin{tabular}{lccccc}
\hline \multirow{2}{*}{$\begin{array}{l}\text { Skala (nazwa } \\
\text { bieguna } \\
\text { pozytywnego) }\end{array}$} & INWALIDA & INWALIDKA & KOBIETA & $\begin{array}{c}\text { INWALIDA- } \\
\text {-INWALIDKA }\end{array}$ & $\begin{array}{c}\text { INWALIDKA- } \\
\text {-KOBIETA }\end{array}$ \\
\cline { 2 - 6 } towarzyska & 67,775 & 63,725 & 115,60 & 1,000000 & 0,000003 \\
\hline mądra & 67,400 & 70,513 & 107,94 & 1,000000 & 0,001820 \\
\hline dominująca & 60,875 & 69,725 & 116,20 & 1,000000 & 0,000044 \\
\hline użyteczna & 59,700 & 65,625 & 120,61 & 1,000000 & 0,000001 \\
\hline niekonfliktowa & 87,625 & 98,237 & 41,950 & 1,000000 & 0,000000 \\
\hline aktywna & 65,463 & 60,013 & 119,69 & 1,000000 & 0,000000 \\
\hline pewna siebie & 68,200 & 66,450 & 121,28 & 1,000000 & 0,000001 \\
\hline zadbana & 64,875 & 62,175 & 132,99 & 1,000000 & 0,000000 \\
\hline samodzielna & 54,575 & 69,838 & 123,81 & 0,844201 & 0,000001 \\
\hline śmiała & 68,900 & 70,825 & 111,04 & 1,000000 & 0,000003 \\
\hline radosna & 65,950 & 71,425 & 109,91 & 1,000000 & 0,001219 \\
\hline energiczna & 73,537 & 65,575 & 116,61 & 1,000000 & 0,000005 \\
\hline zdolna & 59,063 & 71,950 & 110,00 & 1,000000 & 0,001440 \\
\hline niezależna & 58,525 & 75,450 & 108,78 & 0,613983 & 0,007782 \\
\hline zaradna & 69,963 & 70,950 & 110,01 & 1,000000 & 0,000978 \\
\hline twórcza & 68,138 & 65,237 & 95,188 & 1,000000 & 0,023050 \\
\hline
\end{tabular}




\section{Podsumowanie i wnioski}

Badania tego typu pokazują jedynie, że respondent w momencie $(\mathrm{t})$ pod wpływem sytuacji i instrukcji badawczej zaktywizował pewną wiedzę (X), jednakże można uznać, iż podobieństwa i kontrasty ukazane w analizach pozwalają na określenie roli niepełnosprawności jako czynnika budującego mentalne reprezentacje kategorii. Wyniki badania potwierdziły dominującą rolę czynnika niepełnosprawności w sposobie kształtowania reprezentacji kategorii INWALIDKA. Okazało się, że decyduje on o wytworzeniu bardzo dużej różnicy między kategorią KOBIETA a węższą kategorią INWALIDKA, upodabniającą się w znacznym stopniu do kategorii INWALIDA. Jeśli większość reakcji podawanych w teście swobodnych skojarzeń traktujemy jako cechy budujące prototyp danej kategorii, to zrekonstruowane obrazy wskazują na brak dziedziczenia prototypu między KOBIETĄ a podrzędnym pojęciem INWALIDKI. Mamy tu do czynienia jakby z tłumieniem cech jednej kategorii przez właściwości drugiej.

Współczesna KOBIETA, przynajmniej w opinii młodych respondentów, jest dość samodzielna, energiczna i aktywna (oceny w teście skal wynosiły najczęściej 5). Wyniki takie można potraktować jako częściowe potwierdzenie skuteczności działań feministycznych, mających na celu wyzwolenie kobiet z zależności i bierności, a także likwidację tradycyjnego obrazu żony i matki: kobieta, nie tracąc atrybutów swojej seksualności, powinna być samodzielną, czynną zawodowo, mającą równe prawa partnerką dla mężczyzny. Wskazywana przez wyniki badania realność realizacji tych celów w odniesieniu do kobiety kontrastuje z brakiem postrzegania kobiet niepełnosprawnych nawet jako pełniących role żon i matek.

Stwierdzenie dominacji czynnika niepełnosprawności w konstrukcji kategorii złożonych w umysłach osób w wieku 15-18 lat może stanowić podstawę tezy nie tylko o konieczności dalszego upowszechniania działań prointegracyjnych, ale także o potrzebie zaplanowania nowych metod w polityce integracyjnej, które można byłoby skutecznie stosować w środowisku osób dorastających i młodych dorosłych, w tym w szkołach masowych, w których nie ma uczniów z niepełnosprawnością.

Przedstawiony przykład badania wydaje się zatem potwierdzać przydatność perspektywy psychosemantycznej do wspierania czy uzupełniania rozważań i badań nad niepełnosprawnością oraz problemem integracji. Perspektywa ta może stanowić istotny przyczynek do pogłębiania analizy relacji kobieta niepełnosprawna społeczeństwo lub, szerzej, osoby niepełnosprawne - społeczeństwo. 


\section{Bibliografia}

Aitchison J. (2003). Words in the mind. An introduction to the mental lexicon. Oxford (UK), Cambridge (USA): Blackwell.

Atran S. (1999). Itzaj Maya folkbiological taxonomy: cognitive universals and cultural particulars. W: Medin D.L., Atran S. (red.). Folkbiology. Cambridge (Mass.): MIT Press, s. 119-203.

Barnes C., Mercer G. (2003). Disability. Cambridge: Polity Press.

Biernat M., Dovidio J.F. (2003). Stigma and stereotypes. W: Heatherton T.F., Kleck R.E., Hebl M.R., Hull J.G. (red.). The social psychology of stigma. New York: Guilford, s. 88-125.

Byra S. (2010). Mechanizmy kształtowania się stereotypów dotyczacych osób z niepełnosprawnościa. W: Chodkowska M., Byra S., Kazanowski Z., Osik-Chudowolska D., Parchomiuk M., Szabała B. Stereotypy niepełnosprawności. Między wykluczeniem a integracją. Lublin: UMCS, s. 33-48.

Collins A.M., Loftus E.F. (1975). A spreading-activation theory of semantic processing. „Psychological Review”, nr 82, s. 407-428.

Collins A.M., Quillian M.R. (1969). Retrieval time from semantic memory. „Journal of Verbal Learning and Verbal Behavior", nr 8, s. 240-247.

Conklin H.C. (1962). Lexicographical treatment of folk taxonomies. W: Householder F.W., Saporta S. (red.). Problems in lexicography. Bloomington: University of Indiana, s. 119-141.

Connor D., Bejoian L. (2007). Crippling school curricula: 20 ways to teach disability. "Review of Disability Studies: An International Journal”, nr 3, s. 3-13.

Deegan M.J. (1985). Multiple minority groups: a case study of physically disable women. W: Deegan M.J., Brooks N.A. (red.). Women and disability. The double handicap. New Brunswick (USA), Oxford (UK): Transaction Books, s. 37-55.

Dykcik W. (2005). Pedagogika specjalna wobec aktualnych sytuacji i problemów osób niepełnosprawnych. Poznań: PTP.

Eyre P. (2014). Impaired or empowered? W: Bolt D. (red.). Changing social attitudes toward disability. Perspectives from historical, cultural, and educational studies. London, New York: Routledge, Taylor \& Francis Group, s. 99-108.

Fawcett B. (2000). Feminist perspectives on disability. Harlow, London, New York: Prentice Hall.

Fine M., Asch A. (1988). Beyond pedestals. W: Fine M., Asch A. (red.). Women with disabilities: essays in psychology, culture and politics. Philadelphia: Temple University Press.

Fine M., Asch A. (1985). Disabled women: sexism without the pedestal. W: Deegan M.J., Brooks N.A. (red.). Women and disability. The double handicap. New Brunswick (USA), Oxford (UK): Transaction Books, s. 6-22. 
Garland-Thomson R. (2004). Integrating disability, transforming feminist theory. W: Smith B.G., Hutchison B. (red.). Gendering disability. New Brunswick (USA), London: Rutgers University Press, s. 73-103.

Gorajewska D. (2006). Fakty i mity o osobach z niepetnosprawnością. Warszawa: Integracja.

Graham H. (1997). Feminist perspectives on caring. W: Bornat J., Johnson J., Pereira C., Pilgrim D., Williams F. (red.). Community care: a reader. Basingstoke: Open University Press/Macmillan, s. 124-133.

Grzesiak H. (2011/2012). Kulturowe aspekty niepełnosprawności. W: Piekut-Brodzka D.M. (red.). Zrozumieć odmienność. Warszawa: Wydawnictwo Naukowe ChAT, S. 34-58.

Hodkinson A. (2014). Ethnic cleansing? Disability and the colonisation of the intranet. W: Bolt D. (red.). Changing social attitudes toward disability. Perspectives from historical, cultural, and educational studies. London, New York: Routledge, Taylor \& Francis Group, s. 121-131.

Kutza E.A. (1981). Benefits for the disabled: how beneficial for women? "Journal of Sociology and Social Welfare", nr 8, s. 2.

Kwiatkowska A. (1999). Siła tradycji i pokusa zmiany, czyli o stereotypach płciowych. W: Miluska J., Boski P. (red.). Męskość - kobiecość w perspektywie indywidualnej i kulturowej. Warszawa: Instytut Psychologii PAN, s. 143-172.

Lejzerowicz M., Książkiewicz I. (2012). Osoba z niepetnosprawnościq a instytucje pomocowe. Wrocław: Gaskor.

Levinson S.C. (1999). From outer to inner space: linguistic categories and non-linguistic thinking. W: Nuyts J., Pederson E. (red.). Language and conceptualization. Cambridge: University Press, s. 13-45.

Lonsdale S. (1990). Women and disability. The experience of physical disability among women. New York: St. Martin's Press.

Łuszczyńska M., Baum M. (2011/2012). Inność - stygmat czy wyzwanie rozwojowe? W: Piekut-Brodzka D.M. (red.). Zrozumieć odmienność. Warszawa: Wydawnictwo ChAT, s. 7-33.

Macrae C.N., Bodenhausen G.V., Milne A.B. (1995). The dissection of selection in social perception: inhibitory processes in social stereotyping. „Journal of Personality and Social Psychology", nr 69, s. 397-407.

Marszałek L. (2006). Niepetnosprawność - kobiecość - rodzina. Warszawa: Wydawnictwo Uniwersytetu Kardynała Stefana Wyszyńskiego.

Martínez-Manrique F. (2010). On the distinction between semantic and conceptual representation. „Dialectica”, nr 64, s. 57-78. DOI: 10.1111/j.1746-8361.2010.01226.x.

Matthews G.F. (1983). Voices from the shadows: women with disabilities speak out. Toronto: The Women's Press.

Meekosha H., Dowse L. (1997). Distorting images, invisible images: gender, disability and the media. „Media International Australia”, nr 84, s. 91-101. 
Mikołajczak-Matyja N. (2016). Disability or femininity? The role of disability factor and sex factor in building mental representation of a compound social category. "Journal of Global Research in Education and Social Science”, 7 (4), 188-199.

Mikołajczak-Matyja N. (2008). Hierarchiczna struktura leksykonu umysłowego. Relacje semantyczne w leksykonie widzących i niewidomych użytkowników języka. Poznań: Wydawnictwo Naukowe UAM.

Mikołajczak-Matyja N., Niećko-Bukowska B., Anders J. (2013). Stereotypy kobiet $w$ badaniach semantycznych. Porównawcze obrazy pojęciowych reprezentacji kategorii złożonych. Poznań: Wydawnictwo Naukowe UAM.

Miller G.A., Johnson-Laird P.N. (1976). Language and perception. Cambridge, London, Melbourne: Cambridge University Press.

Neef M., Vater H. (2006). Concepts of the lexicon in the theoretical linguistics. W: Wunderlich D. (red.). Advances in the theory of the lexicon. Berlin, New York: Mouton de Gruyter, s. 27-55.

Nowak A. (2012). Zagrożenie wykluczeniem społecznym kobiet niepetnosprawnych. Katowice: Uniwersytet Śląski.

Ogden C.K., Richards I.A. (1923). The meaning of meaning: a study of the influence of language upon thought and of the science of symbolism. London: Kegan Paul, Trench, Trubner \& Co.

Oliver M. (1996). Understanding disability: from theory to practice. Basingstoke: Macmillan.

Ostrowska A. (200o). Niepełnosprawność. W: Encyklopedia socjologii. T. 2. Warszawa: Oficyna Naukowa.

Ostrowska A. (2002). Społeczeństwo polskie wobec osób niepełnosprawnych. Przemiany postaw i dyskursu. W: Sikorska J. (red.). Społeczne problemy osób niepetnosprawnych. Warszawa: Wydawnictwo Instytutu Filozofii i Socjologii PAN, s. 51-64.

Ostrowska A., Sikorska J. (1997). Niepełnosprawność kobiet. Płeć jako dodatkowy czynnik marginalizujący. „Problemy Rehabilitacji Społecznej i Zawodowej”, nr 1, s. 54-64.

O’Toole C.J. (2004). The sexist inheritance of the disability movement. W: Smith B.G., Hutchison B. (red.). Gendering disability. New Brunswick (NJ), London (UK): Rutgers University Press, s. 294-300.

Panek M.P. (2012). Wymiary niepetnosprawności. Gdynia: Novae Res Wydawnictwo Innowacyjne.

Przyłuska-Fiszer A. (2013). Niepełnosprawność jako przedmiot refleksji bioetycznej. Kraków: Wydawnictwo Fall.

Renzetti C.M., Curran D.J. (2003). Women, men, and society. Boston: Allyn \& Bacon. Schneider D.J. (2004). The psychology of stereotyping. New York, London: The Guilford Press.

Schneider D.J. (1999). Współczesne badania nad stereotypami: niedokończone zadanie. W: Macrae C.N., Stangor Ch., Hewstone M. (red.). Stereotypy i uprzedzenia, 
tłum. Majchrzak M., Kacmajor A., Kacmajor M., Nowak A. Gdańsk: Gdańskie Wydawnictwo Psychologiczne, s. 335-367.

Schur L. (2004). Is there still a „double handicap"? Economic, social, and politic disparities experienced by women with disabilities. W: Smith B.G., Hutchison B. (red.). Gendering disability. New Brunswick (USA), London: Rutgers University Press, s. 253-271.

Shakespeare T. (1996). Disability, identity, difference. W: Barnes C., Mercer G. (red.). Exploring the divide: ilness and disability. Leeds: The Disability Press, s. 94-113. Shaul S., Dowling P.J., Laden B.F. (1985). Like other women: perspectives of mothers with physical disabilities. W: Deegan M.J., Brooks N.A. (red.). Women and disability. The double handicap. New Brunswick (USA), Oxford (UK): Transaction Books, s. 33-142.

Smith B.G. (2004). Introduction. W: Smith B.G., Hutchison B. (red.). Gendering disability. New Brunswick (USA), London: Rutgers University Press, s. 1-6.

Thomas C. (1999). Female forms. Experiencing and understanding disability. Buckingham, Philadelphia: Open University Press.

Tulving E. (1972). Episodic and semantic memory. W: Tulving E., Donaldson W. (red.). Organization of memory. New York: Academic Press, s. 380-402.

Vernon A. (1996). Fighting two different battles: unity is preferable to enmity. „Disablity and Society”, nr 11, s. 285-290.

Zahorodna K. (2015). Problem reprezentacji umysłowych $w$ rozszerzonych systemach poznawczych. Wrocław: Fundacja na rzecz Nauki Polskiej, dostępny na www. academia.edu/14373594/Katarzyna_Zahorodna (otwarty 1.03.2016).

\title{
INVESTIGATING THE ROLE OF DISABILITY FACTOR IN BUILDING MENTAL REPRESENTATION OF COMPOUND CATEGORY
}

\begin{abstract}
The paper makes a contribution to the problem of integration by suggesting the possibility of including into the spectrum of research on issues related to integration psychosemantic analyses - the study of mental representations of categories related with disability. A method of analysing the structure of categories of subgroups of disabled people (which are subject to the so called "multiple oppression") is proposed. Such type of categories should be analysed as compound categories subordinate to two or more superordinate/simple categories, and the structure of the compound category should be examined in terms of the degree of its similarity to each superordinate category. The example of psychosemantic research on the category of disabled women is presented. The unique specifics of oppression typical for this subgroup of disabled people, determining the structure of the compound category and its relations with superordinate categories (a woman and a disabled person), can be seen as the result of treating dysfunction as a factor creating a gap between disabled women and prototypical femininity by hindering the effective fulfilment of traditional female roles. The results of the presented study - test
\end{abstract}


of associations and test of scales - confirm a very large difference between the narrower category of disabled woman and the more general category of woman as well as the much stronger and dominant role of the disability factor in the process of building the representation of the compound category.

Key words: concepts, mental representation, semantic memory, mental lexicon, disability, feminism, disabled woman, integration

Nawoja Mikołajczak-Matyja - profesor UAM, doktor habilitowana w Zakładzie Psycholingwistyki Instytucie Językoznawstwa Uniwersytetu im. Adama Mickiewicza w Poznaniu. Główne zainteresowania naukowe: leksykalne i semantyczne aspekty psycholingwistyki, leksykografia, semantyka, psychologia procesów poznawczych, psychopatologia. Autorka monografii: Definiowanie pojęć przez przeciętnych użytkowników języka i przez leksykografów (1998) i Hierarchiczna struktura leksykonu umysłowego. Relacje semantyczne w leksykonie widzących i niewidomych użytkowników języka (2008) oraz współautorka monografii Skojarzenia słowne w psycholeksykologii i onomastyce psycholingwistycznej (2002) i Stereotypy kobiet w badaniach psychosemantycznych. Porównawcze obrazy pojęciowych reprezentacji kategorii złożonych (2014). Adres do korespondencji: al. Niepodległości 4, 61-874 Poznań. Adres e-mail: nawomiko@amu.edu.pl. 